\title{
Testing a continuous variation in preweaning expression of muscular hypertrophy in beef cattle using field data
}

\begin{abstract}
Summary
The hypothesis of a continuous variation in the expression of muscular hypertrophy has been tested using field data. A modification of NEUVY and VISSAC's cularity index method (Culard Index) was assayed. Expression of muscular hypertrophy showed a broad phenotypical variability. Environmental factors affecting expression of muscular hypertrophy characterised by Culard Index were calving season, age of dam, sex of calf, muscularity of dam, muscularity of sire and age of calf at weaning. In addition, Culard Index influences significantly preweaning growth traits confirming double muscled calves' higher preweaning growth ability. Culard Index score showed moderate heritability. Expression of muscular hypertrophy could be a relatively different trait with respect to latent muscular hypertrophy that would be, in turn, determined by a partially dominant major gene. Culard Index could be an interesting tool to make use of the observable differences in expression of muscular hypertrophy.
\end{abstract}

Key Words: beef cattle; muscular development; heritability; culard index; preweaning traits; Asturiana de los Valles

\section{Zusammenfassung}

Titel der Arbeit: Einflussfaktoren, Variation und Erblichkeit der Ausprägung von Muskelhypertrophien bei Saugkälbern von Fleischrindern

Die Hypothese einer kontinuierlichen Variation in der Ausprägung der Muskelhypertrophie wurde mittels Felddaten getestet. Hierzu wurde eine Modifikation der Methode nach NEUVY und VISSAC für den Geburtsindex angewendet. Die Ausprägung der Muskelhypertrophie zeigte eine starke, phänotypische Variabilität. Die Umweltfaktoren, die die Ausprägung der Muskelhypertrophie beinflussten waren Abkalbzeit, Muskelbeschaffenheit der Elterntiere und Geschlecht der Kälber zum Entwöhnungszeitpunkt. Der Grad der Ausprägung der Muskelhypertrophie beeinflusste zudem die Wachstumsmerkmale der Kälber vor der Entwöhnung. Kälber mit Muskelhypertrophie zeigten ein stärkeres Wachstumsvermögen. Die Ausprägung der Muskelhypertrophie ist jedoch nur schwach vererbbar. Die phänotypische Ausprägung der Muskelhypertrophie könnte neben der genetischen. Bestimmung ein zusätzliches Zuchtmerkmal darstellen. Der veränderte Geburtsindex nach NEUVY und VISSAC könnte ein nützliches Hilfsmittel sein, um die Unterschiede in der Ausprägung der Muskelhypertrophie in der Praxis zur Anwendung zu bringen, z.B. in Zuchtprogrammen von Rinderrassen mit hoher Frequenz an Tieren mit Muskelhypertrophie.

Schlüsselwörter: Fleischrassen, Entwicklung der Muskulatur, Heritabilität, Muskelhypertrophieindex, Wachstum Saugkälber, Asturiana de los Valles

\section{Introduction}

Monogenic determination of Muscular Hypertrophy $(\mathrm{MH})$ has been established since the 80's (HANSET and MICHAUX, 1985). On a molecular level, MH would be determined by a partially dominant mutation in bovine MSTN gene, which encodes myostatin (GROBET et al., 1997). However there is a high variability in phenotypic expression of muscular hypertrophy. Observed individual differences in expression of $\mathrm{MH}$ do not match with expectation if observable degree of $\mathrm{MH}$ were only dependent on a major gene. For instance, Blanc-Bleu Belge cattle and other cattle breeds, such as Asturiana de 
los Valles, have the same mutation of the myostatin gene (an 11-bp deletion in the coding sequence) (GROBET et al., 1997) responsible of double muscled phenotype, but degree of expression of $\mathrm{MH}$ varies widely both inter and intra breeds. Seemingly, individual differences in the $\mathrm{MH}$ expression seem to be susceptible to change by selection as it has been successfully done in Blanc-Bleu Belge cattle (HANSET, 1999, personal communication). Difficulties in finding out the causes of MH expression variability in cattle are not new, being the conceivable presence of modifier genes with additive effect affecting the expression of partially dominant gene the most accepted hypothesis to explain these differences (MENISSIER, 1982).

Presence of mutation causing $\mathrm{MH}$ can be desirable in cattle to obtain certain meat characteristics such as leanness or tenderness. However, modulation of $\mathrm{MH}$ expression could be interesting to avoid undesirable effects of double muscling affecting animal welfare, such as calving problems. Since large-scale genotyping of myostatin gene in a given cattle population is not realistic in economic terms it would be useful to develop new tools to take advantage of $\mathrm{MH}$ expression variability. In order to achieve the use in breeding programs of the observed individual differences in $\mathrm{MH}$ expression it is necessary to implement a methodology able to measure objectively the phenotypical degree of $\mathrm{MH}$. The use of some indices assuming a continuous variation of $\mathrm{MH}$ expression has been proposed (NEUVY and VISSAC, 1962; ROLLINS et al., 1972). However, none of them has been employed on a large scale. In addition, papers concerning its use in real conditions are scarce and based on narrow samples (LOGEAY and VISSAC, 1970; VALLS et al., 1972).

"Asturiana de los Valles" (AV) is a Spanish beef cattle breed, exploited mostly in traditional conditions in the mountains of the north of Spain (GOYACHE et al., 2000). $\mathrm{MH}$ presence at the AV breed has been related since the 30's, and its diffusion into the breed has been continuous due to economical reasons. $\mathrm{MH}$ affects dramatically the sale price of animals. Culard carcasses have a carcass price per $\mathrm{Kg}$ up to $40 \%$ higher to normal ones. In this market conditions, knowledge and use of muscular hypertrophy is a major goal in AV improvement program. Despite the presence of MH in almost all sires, there is still a high percentage of phenotypically normal cows, regardless their actual myostatin genotype, to maintain good maternal characteristics. It is possible to find a high variability of $\mathrm{MH}$ expression in calves.

The objective of this paper is to test the ability of a new index to characterise the observable variation in expression of $\mathrm{MH}$ assuming a continuous variation of the trait and to estimate environmental and genetic factors affecting preweaning muscular hypertrophy expression using AV breed field data.

\section{Material and methods}

The Regional Government of Principado de Asturias, through the Asturiana de los Valles Breeders Association (ASEAVA), have implemented performance recording (CORECA database) based on nuclei grouping farms according to their proximity and their production system arising from small farm size (GOYACHE et al., 2000; GOYACHE and GUTIERREZ, 2001).

Degree of observable muscularity, as a measure of the degree of expression of a possible subjacent $\mathrm{MH}$, is usually recorded categorically in AV breed improvement program. Sires and dams are phenotypically assessed according to their general muscularity as 0 (poor muscular development), 1 (good muscular development) and 2 
(excellent muscular development) by trained ASEAVA's classifiers. Muscularity of calves at birth is assessed by breeders following the same methodology. Class 0 is expected to include genotypically normal animals and heterozygous animals with a poorer expression of $\mathrm{MH}$ characteristics. Class 2 is expected to contain all the phenotypically double muscled animals.

Table 1

Characters considered building Cularity Index, age of maximum expression of each character, and AV performance recording modification

\begin{tabular}{|c|c|c|c|}
\hline Character* & Score & AV modification & Age of maximum expresivity** \\
\hline A. Macroglosy & $0,1,2$ & No & $\begin{array}{l}\text { Birth. Dessapear in three weeks old } \\
\text { calves }\end{array}$ \\
\hline B. Muscularity of shoulders & $0,1,2$ & $\mathrm{x} 2$ & From 3 months to 1 year \\
\hline C. Compacity degree & $0,1,2$ & $\dagger$ & All life \\
\hline Rear legs & $0,1,2$ & $\dagger$ & All life \\
\hline D. Abdomen retraction & $0,1,2$ & $\dagger$ & From 3 months to 1 year \\
\hline E. Pelvic inclination & $0,1,2$ & $\dagger$ & All life \\
\hline F. Attachment point of the tail & $0,1,2$ & $\dagger$ & All life \\
\hline G. Muscularity of legs & $0,1,2$ & $\mathrm{x} 2$ & From 3 months to 1 year \\
\hline $\begin{array}{l}\text { H. Shoulders and hindquarters } \\
\text { depressions }\end{array}$ & $0,1,2$ & No & From 3 months to 1 year \\
\hline I. Fineness of bones & $0,1,2$ & $\dagger$ & All life \\
\hline Total score & 20 & 20 & \\
\hline
\end{tabular}

A modification of the cularity index proposed by NEUVY and VISSAC (1962) was assayed to measure accurately the degree of expression of muscular hypertrophy of calves at weaning. The traits involved and differences with NEUVY and VISSAC's method are shown at Table 1. Doubtful or age dependent traits have been excluded from the new index. Macroglosy disappears quickly after birth. Intermuscular depressions of shoulders and hindquarters are not exclusive of double muscled animals and they can be observed even in poorer muscled animals when they are under a very low feeding regime. Traits scoring muscularity have been more weighted in the determination of the new cularity index than in the original one. The maximum score is still 20 and the minimum (total absence of observable muscular hypertrophy) is 1 . CI is supposed to be effective at every economically important age of calf (weaning and fattening) regardless of availability of previous information about calf. Assuming the notation of the involved traits showed in Table 1, CI can be expressed as

$$
\mathrm{CI}=2 \cdot \mathrm{B}+\mathrm{C}+\mathrm{D}+\mathrm{E}+\mathrm{F}+2 \cdot \mathrm{G}+\mathrm{I}
$$

Each one of the traits building $\mathrm{CI}$ is scored as 0,1 or 2 for no expression, intermediate expression and full expression of MH characteristics, respectively.

CI scores have been recorded at weaning by trained ASEAVA's classifiers. The classifier who carried out CI scores in a given management group was always the same. Performance of classifiers was routinely checked to avoid individual differences in scores. Scores from 1 to 6 are expected to include phenotypically normal muscled calves 
at weaning; scores from 7 to 10 are expected to include phenotypically intermediate muscled calves and from 11 to 19 clearly double muscled calves. Notice that classes grouping CI scores, like classifications of degree of observable muscularity in sires, dams or calves at birth, do not match with actual myostatin genotypes of the assessed animals. Up to 2,604 cularity index observations were available. Because of the nonexperimental origin of data, only records including degree of muscularity of sire and dam, weight and degree of muscularity of calf at birth, and weaning weight of calf were accepted for statistical analysis. Records were deleted in all cases of twin calving, uncertain calving number or doubtful calf sex. Records out of range 90 to 270 days of age at weaning were also removed from the analysis. Finally 2,493 records were analysed.

\section{Statistical analysis}

The statistical analysis was done with GLM Procedure of SAS (SAS, 1999). Sum of squares were estimated using Type III test. DUNCAN's multiple-range test was performed on all main-effect means affecting CI.

Table 2

Degrees of freedom, mean squares, f-values and significance of phenotypic sources of variation affecting culard index

\begin{tabular}{llcc}
\hline Sources of variation & d.f. & Mean square & F-value \\
\hline Management group & 37 & 139.3 & $11.49^{* * *}$ \\
Month of calving & 11 & 31.5 & $2.60^{* *}$ \\
Calving number & 5 & 45.8 & $3.78^{* *}$ \\
Sex of calf & 1 & 205.9 & $16.98^{* * *}$ \\
Muscularity of sire & 2 & 58.1 & $4.79^{*}$ \\
Muscularity of dam & 2 & 767.1 & $63.27^{* * *}$ \\
Covariate age at weaning & 1 & 221.3 & $18.25^{* * *}$ \\
\hline
\end{tabular}

CI analysis model (Table 2) included as fixed effects: management group by year of calving, calving month, calving number, calf sex, muscularity of dam, and muscularity of sire; age at weaning was included as a linear covariate.

CI effect productive characters was analysed as independent variable for birth weight, actual weaning weight, 180-days adjusted weaning weight; dystocia was treated as a continuous trait from 1 (no-assistance) to 4 (caesarea). All fitted models included the same fixed effects: management group by year of calving, calving month, calving number, calf sex, muscularity of dam, and CI as a linear and quadratic covariate. Previous analysis showed that muscularity of sire did not influence significantly on productive traits; in consequence this effect was not included in the fitted model. Preweaning growth trait models included age at weaning as a linear covariate. Dystocia model, included birth weight as a linear covariate to take into account the major influence of calf size on calving ease.

\section{Genetic parameters}

Genetic parameters affecting CI, considered as a continuous trait, were analysed with Meyer's DFREML program (1991) under an animal model. The program has been restarted with different $a$ priori values of the genetic parameters to avoid confusion arising from the possible existence of local maxima. 
Table 3

Structure of data used for the estimation of genetic parameters of culard index in AV breed

\begin{tabular}{ll}
\hline Structure of data & \\
\hline Number of animals & 4,849 \\
Animals with record & 2,508 \\
Sires & 349 \\
Dams & 2,031 \\
Animals in model & 4,849 \\
Sires with record and offspring & 12 \\
Dams with record and offspring & 27 \\
Environmental effects & \\
Nucleus-year & 39 \\
Calving season & 3 \\
Calving number & 4 \\
Calf sex & 2 \\
Age at weaning & 1 \\
\hline
\end{tabular}

Since birth and weaning weight were not necessary for genetic analysis, 2,508 records were available. Structure of analysed data is shown in Table 3. Fitted model included five fixed effects: management group by year of calving as a comparison group, period of calving, calving number, sex of calf and age at weaning as a linear covariate. The random effects included the additive genetic effect, the maternal genetic effect, the covariance between both direct and maternal genetic effects being its variancecovariance matrix proportional to the additive numerator relationship matrix, and the residual. Described model was used before to analyse genetic parameters of preweaning growth traits in AV breed (GUTIERREZ et al., 1997).

Total heritability $\left(\mathrm{h}_{\mathrm{T}}^{2}\right)$ has been calculated with the formula $\mathrm{h}_{\mathrm{T}}^{2}=\left(\sigma_{\mathrm{a}}^{2}+1.5 \sigma_{\mathrm{am}}+\right.$ $\left.0.5 \sigma_{\mathrm{m}}^{2}\right) / \sigma^{2}$ (DICKERSON 1947), being $\sigma^{2}$ the phenotypic variance

\section{Results}

Phenotypic CI mean, considered as a continuous variable, was 8,6 and had a high coefficient of variation (46.5\%). Descriptive statistics of CI by major sources of variation

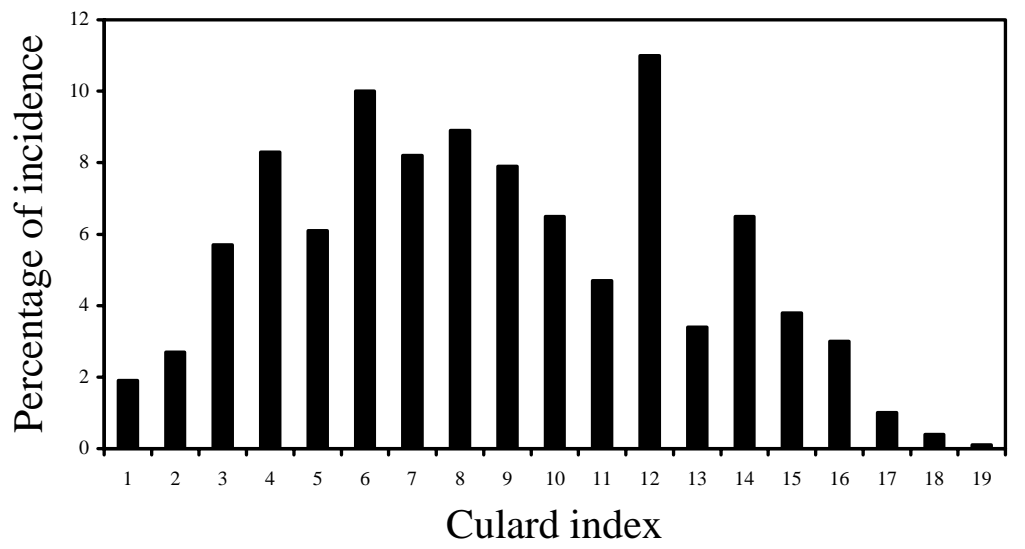

Fig. 1: Frequency of culard index score (in percentage) in the analysed database

are shown in Tables 4 and 5. Phenotypic CI mean seems rather constant despite the influence of calf sex or calving number. As it was expected, CI shows no normal distribution (Kolmogorov Test: 0.091, $\mathrm{P}<0.01$ ) (Fig. 1) and a mode of 12 (11\% of the 
incidence) very close to the 6 incidence (10\%). A CI below 7 (phenotypically normal animals) was found in $34.6 \%$ of calves, whereas a CI above 10 (double muscled animals) appeared in $33.9 \%$ of them. CI shows a close correlation with calf muscularity assessment at birth $(\mathbf{r}=0.69)$. $70 \%$ of calves assessed as double muscled at birth are weaned with a CI above to 10 (Table 5). Only 6\% of double muscled calves at birth presented a CI lower than 7. A 51\% of calves classified as 1 at birth had at weaning with CI between 7 and 10, but $36 \%$ are weaned with CI above to 10 . A $66 \%$ of class 0 calves

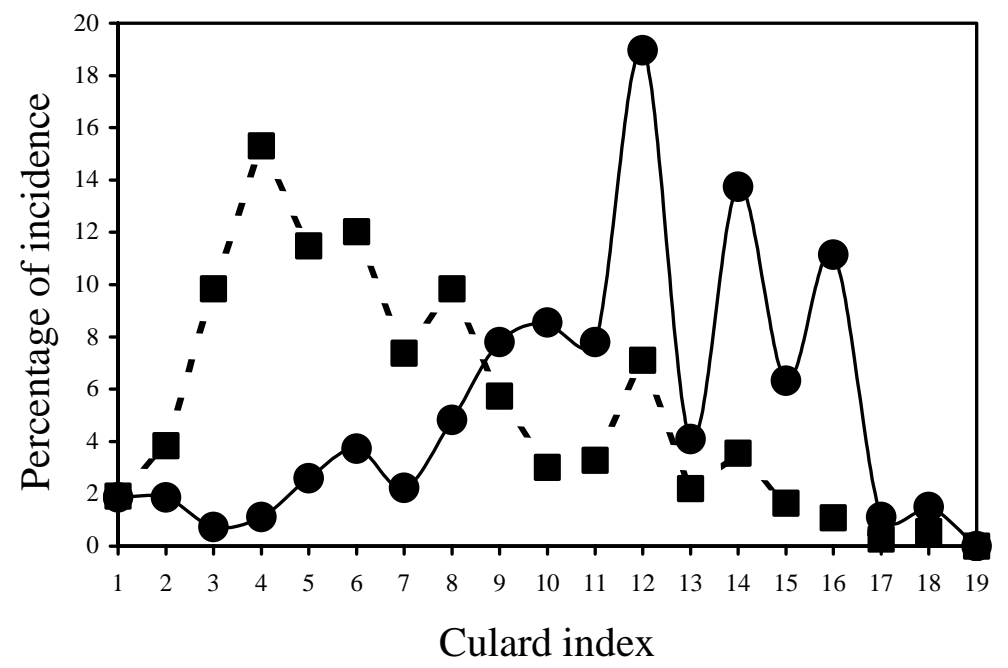

Fig. 2: Frequency of Culard index score (in percentage) by parents’ muscularity score. (घ) Class 0 sires’ offspring. (•) Class 2 dams’ offspring

Table 4

Least squares means, standard errors (s.e.) and mode of culard index as a continuous variable by the major sources of variation

\begin{tabular}{|c|c|c|c|c|}
\hline & Number & Mean & s.e. & Mode \\
\hline \multicolumn{5}{|c|}{ Muscularity of sire } \\
\hline Class $2^{\mathrm{a}}$ & 1,738 & 9.6 & 0.23 & 12 \\
\hline Class $1^{\mathrm{b}}$ & 389 & 9.2 & 0.14 & 4 \\
\hline Class $0^{\mathrm{C}}$ & 366 & 8.9 & 0.24 & 4 \\
\hline \multicolumn{5}{|c|}{ Muscularity of dam } \\
\hline Class $2^{\mathrm{a}}$ & 269 & 10.4 & 0.24 & 12 \\
\hline Class $1^{\mathrm{b}}$ & 288 & 9.4 & 0.24 & 12 \\
\hline Class $0^{\mathrm{C}}$ & 1,936 & 8.0 & 0.14 & 6 \\
\hline \multicolumn{5}{|l|}{ Sex of calf } \\
\hline Male $^{\mathrm{a}}$ & 1,280 & 9.6 & 0.17 & 12 \\
\hline Female $^{\mathrm{b}}$ & 1,213 & 9.0 & 0.17 & 12 \\
\hline \multicolumn{5}{|l|}{ Calving number } \\
\hline First $^{\mathrm{b}}$ & 386 & 8.7 & 0.22 & 12 \\
\hline Second $^{\mathrm{ab}}$ & 366 & 9.4 & 0.22 & 8 \\
\hline Third $^{\mathrm{a}}$ & 345 & 9.5 & 0.23 & 12 \\
\hline Fourth $^{\mathrm{a}}$ & 335 & 9.6 & 0.23 & 12 \\
\hline Form 5 to $9^{\mathrm{ab}}$ & 939 & 9.5 & 0.17 & 12 \\
\hline More than $9^{\mathrm{ab}}$ & 122 & 8.8 & 0.35 & 7 \\
\hline
\end{tabular}

Unequal letters express means significantly differences for $\mathrm{P}<0.05$.

at birth are weaned with CI below 7. A high percentage of calves classified as 0 (34.3\%) are weaned with CI higher than 6 .

Most parents in the AV population are phenotypically normal dams (class 0) and double muscled sires (class 2). Therefore, CI distributions of their offspring are very close 
between them and with the general CI distribution (Figure 1). However, the mode of phenotypically poor muscled dams' offspring is at 6 (Table 4). CI distributions of nodouble muscled sires’ offspring are very similar and their mode is 4 (Figure 2). CI frequencies of the offspring of dams scoring 2 or 1 in degree of muscularity are very similar and with mode at 12 (Figure 2).

Table 5

Phenotypic means, standard deviations (s.d.) and frequencies (in percentage) of CI score by muscularity of calf at birth

\begin{tabular}{|c|c|c|c|c|c|c|c|}
\hline \multirow{2}{*}{$\begin{array}{l}\text { Muscularity of } \\
\text { calf at birth }\end{array}$} & \multirow[b]{2}{*}{ Number } & \multirow[b]{2}{*}{ Mean } & \multirow[b]{2}{*}{ s.d. } & \multirow[b]{2}{*}{ Mode } & \multicolumn{3}{|c|}{ CI score frequencies } \\
\hline & & & & & 1 to 6 & 7 to 10 & 11 to 19 \\
\hline Class $2^{\mathrm{a}}$ & 906 & 11.8 & 3.2 & 12 & 5.7 & 24.6 & 69.7 \\
\hline Class $1^{\mathrm{b}}$ & 436 & 9.6 & 3.1 & 8 & 12.8 & 51.0 & 36.2 \\
\hline Class $0^{\mathrm{C}}$ & 1,143 & 5.7 & 2.5 & 6 & 65.7 & 29.8 & 4.5 \\
\hline
\end{tabular}

Unequal letters express means significantly differences for $\mathrm{P}<0.05$.

The use of sires scoring 0 or 1 for muscularity gives a high probability to obtain a poorly muscled calf at weaning, unlike the use of good or excellent conformed dams. It could be partially explained by the fact that the probability of mating class 0 sires with class 0 dams is $8 \%$ superior than with other dam classes, whereas the mating between class 2 sires and class 2 or 1 dams is $11 \%$ more frequent than with poor muscled dams $(\mathrm{P}<0.001)$.

\section{Factors Affecting Culard Index}

Table 2 shows the significance of the sources of variation involved in model adjusted to know the importance of environmental factors affecting the phenotypic expression of muscular hypertrophy. Coefficient of determination was $26.7 \%$, showing highunexplained variability.

Month of calving, calving number of the dam, calf sex, degree of muscularity of the dam, degree of muscularity of the sire and age of calf at weaning influence significantly CI.

CI means are higher in calves born from July to December than in first six months of the year. CI means of calves born in the first half of the year are close to the general CI mean, while calves born in the second half of the year show a CI mean in the $110 \%$ of the general CI mean.

CI means are very close from second calving cows' offspring to adult cows' offspring (Table 4). CI means from heifers and old cows' offspring are 92 and 93\% respectively on adult cows' offspring CI mean. Male calves CI mean is 7\% superior than female calves CI mean.

Degree of muscularity of the sire influences CI in a lesser extent than degree of muscularity of the dam. Muscularity of the dam explains $20 \%$ of the sum of squares of the model and the sire's degree of muscularity explains only $1.5 \%$. Muscled sires' offspring have a CI mean 4 and $7 \%$ superior than classes 0 and 1 sires' offspring respectively. Muscled (Class 2) dams’ offspring present a CI mean 11 and 30\% superior than well and poorer conformed dams' offspring.

CI increases 0.007 units/day with a slope of \pm 0.6 between 3 and 9 months of age. 


\section{CI influence on preweaning traits}

Birth weight, actual weaning weight, 180-days adjusted weaning weight, preweaning average daily gain and incidence of dystocia depend significantly on CI, as a linear covariate. Only birth weight depends significantly on CI, as a quadratic covariate (Table 6). CI explain much of birth weight variance (21.5\% for the linear covariate and $1.7 \%$ for the quadratic covariate) but only $1-3 \%$ of the preweaning growth characters and dystocia.

\section{Table 6}

CI influence on birth weight, weaning weight, 180 days adjusted weaning weight, preweaning average daily gain and dystocia, treated as linear and quadratic covariate

\begin{tabular}{lll}
\hline Dependent variable & Linear covariate & Quadratic covariate \\
\hline Birth weight & $0.42^{* * *}$ & $0.03^{* * *}$ \\
Actual weaning weight & $1.29^{* * *}$ & 0.07 \\
Adjusted weaning weight & $1.34^{* * *}$ & 0.06 \\
Average daily gain & $0.006^{* * *}$ & 0.0002 \\
Dystocia & $0.017^{* * *}$ & 0.0002 \\
\hline$* \mathrm{P}<0.05 ; * * \mathrm{P}<0.01 ; * * * \mathrm{P}<0.001$ & &
\end{tabular}

$\mathrm{CI}$ as a covariate detects differences in preweaning performance at different calf ages. Calves with $\mathrm{CI}=1$ were more than $6 \mathrm{Kg}$ lighter at birth than $\mathrm{CI}=16$ calves. Calves with $\mathrm{CI}=16$ are $20 \mathrm{Kg}$ heavier at weaning and its preweaning average daily gain is $90 \mathrm{~g} /$ day higher than $\mathrm{CI}=1$ calves.

Dystocia increases with CI; $\mathrm{CI}=16$ calves would cause $124 \%$ dystocia than $\mathrm{CI}=1$ calves. The increase of dystocia is higher than for birth weight. The influence of calf birth weight on dystocia has been taken into account in the model as a linear covariate. The higher increase of dystocia than birth weight by CI point could be explained by the action of a threshold for calving ease (MEIJERING 1984).

\section{Genetic Components Affecting Culard Index}

Genetic parameters affecting CI are presented in Table 7. CI in AV breed shows a moderate heritability $(0.19)$ and a lower maternal influence $(0.14)$ with a negative covariance between both parameters. Total heritability (DICKERSON 1947) was 0.20.

Table 7

Genetic parameter values and standard errors (below) affecting Culard Index

\begin{tabular}{llllll}
\hline & $\mathrm{h}^{2}$ & $\mathrm{~m}^{2}$ & $\mathrm{r}_{\mathrm{am}}$ & $\sigma_{\mathrm{am}} / \sigma^{2}$ & $\mathrm{~h}_{\mathrm{T}}$ \\
\hline Culard index & 0.19 & 0.14 & -0.24 & -0.04 & 0.20 \\
\hline & 0.07 & 0.10 & & 0.01 & \\
\hline
\end{tabular}

\section{Discussion}

Results showed in this paper reveal a wide variability in MH expression in AV cattle. These variability is affected by AV breed productive system and empirical selection carried out for breeders. AV dams are exploited in mountainous areas and semiextensive conditions to produce well conformed or double muscled calves at weaning by mating with double muscled AV sires. AV breeders tend to select for reposition dams showing poor muscularity characteristics in adult ages regardless their actual myostatine genotype. These dams are expected to show a better breeding performance than double muscled dams. This is a very important task in a management system in which a half of the calvings are expected to happen without assistance (GOYACHE et al. 2000). 
CI can be useful to characterise this variation in $\mathrm{MH}$ expression. Factors affecting CI are in the same sense than expected according with the literature. $\mathrm{MH}$ is more evident in healthy animals with good feeding (VISSAC and LAUVERGNE, 1968; VISSAC et al. 1973) and is more pronounced in males than in females (MENISSIER 1982). Influence of month of calving and calving number of the dam on CI can be explained taking into account that AV calves born in the second half of year show higher average daily gains at weaning than those born in the first half (data not shown) and the minor ability of heifers and old dams (9 or more calvings, see Table 4) to nurse their offspring. Results concerning the influence of muscularity of dams and sires on CI should be taken with precaution. Muscularity classifications of sires and dams can not be considered an accurate indicator of their actual myostatin genotype. Phenotypes corresponding to homozygous normal and heterozygous animals for myostatin are very close (KIDWELL et al., 1952) and, in consequence, a reliable classification is difficult, specially in breeds showing a good phenotypical muscular development (VALLS et al., 1972). Other factors can affect the classification of muscularity. Degree of muscularity scores the degree of $\mathrm{MH}$ expression at adult age. $\mathrm{MH}$ expression tends to disappear in adult animals and specially in females (VISSAC and LAUVERGNE, 1969).

The way in which age of calf affects CI is according with expected. MH is not always expressed at birth. ROLLINS et al. (1972) found that a 28\% of double muscled calves do not show $\mathrm{MH}$ characteristics at birth. Some $\mathrm{MH}$ characteristics can not be clearly seen until the age of 3 months. It is generally accepted that $\mathrm{MH}$ expression increase from 1 to 18 months; after that time $\mathrm{MH}$ expression would tend to disappear as animals approach the adult age (LAUVERGNE et al., 1963).

In addition to use $\mathrm{CI}$ to characterise observable variation of $\mathrm{MH}$ our index can be used to explain partially the calving and preweaning performance of the calf. Our results are in agreement with literature. Despite the lighter adult weight of double muscled animals it has been stated that double muscled calves have higher average birth weight than normal calves (between 10 and 30\%) and a bigger growth ability than normal ones at young ages (MENISSIER, 1982). According with literature this higher growth ability would get lower with maturity to find lighter weight in adult age. FITZHUGH and TAYLOR (1971) predicted theoretically this growth trend for animals showing a higher maturity (weight at constant age/adult weight) at younger ages.

CI has moderate heritability. This result suggest that CI is not only depending on a major gene. If CI was only dependent on the action of a major gene the estimated heritability should be higher. In this sense MACKELLAR (1968, cited by MENISSIER, 1982) estimated the heritability of the double muscled trait evaluated in 4 classes as $\mathbf{h}^{2}=0.58 \pm 0.08$. Expression of muscular hypertrophy characterised by CI could be a relatively different trait with respect to latent $\mathrm{MH}$, which would be monogenically determined. Some authors suggest that additive modifier genes affecting MH expression are probably responsible for muscular development in normal animals (VALLS ORTIZ et al., 1972; MENISSIER, 1982). SHI et al. (1993), in Limousin cattle, obtained for muscular development at weaning similar estimations of heritability to those obtained at present analysis.

We can not reject that observable variability of $\mathrm{MH}$ expression was partially sustained by the action of additive modifier genes (MENISSIER, 1982). In any case the possible additive genetic influence on $\mathrm{MH}$ expression would take a lesser role. It is always possible that the segregation of myostatin gene was involved in this genetic 
determination, but if we accept that $\mathrm{MH}$ genetic expression mechanism under the responsibility of myostatin gene involves dominance, its participation in the genetic determination of CI could increase residual, and not genetic additive variance.

However, to ascertain this topic it would be necessary to genotype involved animals for myostatin mutations to include unambiguous genotypes in the analysis. This is out of the aim of the present paper. The genetic analysis within available CI classes is not reliable because of it would lead to obtain biased results and would increase the error of the estimations by means of the reduction of useful data.

\section{Implications}

Despite the well-know monogenic determination of muscular hypertrophy in cattle, the $\mathrm{MH}$ expression can be measured as a continuous trait. The index assayed can characterise a wide phenotypical variability in $\mathrm{MH}$ expression.

Our results do not allow to reject the classical hypothesis accepting that observable variability of $\mathrm{MH}$ expression is partially sustained by the action of additive modifier genes affecting expression of a partially dominant major gene (MENISSIER, 1982). In this sense, CI could be an interesting tool to make use of the observable differences in $\mathrm{MH}$ expression. Further research is needed to determine the usefulness of CI to improve the phenotypical classification of the calves as well as their performance according to their $\mathrm{MH}$ genotype. On the other hand, the possible genetic correlation between CI and growth or calving traits should be clarified.

\section{Acknowledgements}

This paper has been partially supported by a grant from CICYT-FEDER, no 1FD971633 and from the Regional Government of the Principado de Asturias through Consejería de Medio Rural y Pesca. Authors would like to thank S. SIDLER for his kind help and comments.

\section{References}

DICKERSON, G.E.:

Composition of hog carcasses as influenced heritable by differences in rate and economy of gain. Iowa. Agric. Exp. Sta. Res. Bull. 354 (1947), 489-524

GOYACHE, F.; GUTIÉRREZ, J.P., FERNÁNDEZ, I.; VILLA, A.; ALVAREZ, I.; RODRÍGUEZ CASTAÑÓN, A.A.; GARCÍA PALOMA, J.A.:

Efectos ambientales que influyen en la dificultad de partos y el peso al nacimiento en la raza Asturiana de los Valles. Arch. Zootec. Córdoba, 49 (2000), 481-492

GOYACHE, F.; GUTIERREZ., J.P.:

Heritability of reproductive traits in Asturiana de los Valles beef cattle breed. Arch. Tierz., Dummerstorf, 44 (2001), 489-496

GROBET, L.; ROYO MARTIN, L.J.; PONCELET, D.; PIROTTIN, D.; BROUWERS, B.; RIQUET, J.; SCHOEBERLEIN, A.; DUNNER, S.; MENISSIER, F.; MASSABANDA, J.; FRIES, R.; HANSET, R.; GEORGES, M.:

A deletion in the myostatin gene causes double-muscling in cattle. Nature Genetics. Basingstoke Hampshire, 17 (1997), 71-74

GUTIÉRREZ, J.P.; CAÑÓN, J.; GOYACHE, F.:

Estimation of direct and maternal genetic parameters for preweaning traits in the Asturiana de los Valles beef cattle breed through animal and sire models. J. Anim. Breed. Genet., 114 (1997), 261-266

HANSET, R.; MICHAUX, C.:

On the genetic determinism of muscular hypertrophy in the Belgian White and Blue cattle breed. I. Experimental data. Génét. Sél. Evol., Les Ulis, 17 (1985), 359-368 
KIDWELL, J.F.; VERNON, E.H.; CROWN, R.M.; SIGLETARY, C.B.:

Muscular hypertrophy in cattle. J. Hered., Oxford, 43 (1952), 62-68

LAUVERGNE, J.J.; VISSAC, B.; PERRAMON, A.:

Etude du caractère culard. I. Mise en point bibliographique. Ann. Zootech. Les Ulis, 12 (1963), 133-156

LOGEAY, B.; VISSAC, B.:

Etude du caractère culard. V. Experience de croisements entre bovins culards et normaux. Ann. Genet. Sel. Anim., Les Ulis, 2 (1970), 5-17

MEIJERING, A.:

Dystocia and stillbirth in cattle. A review of causes, relations and implications. Livest Prod Sci, Amsterdam, 11 (1984), 143-177

MENISSIER, F.:

Present state of knowledge about the genetic determination of muscular hypertrophy or the double muscle trait in cattle. In: KING J.W.B.; MENISSIER F. (Eds.), Muscular Hypertrophy of Genetic Origin and its Use to Improve Beef Production. Curr. Top. Vet. Anim. Sci., Amsterdam, 16 (1982), 387-428

MEYER, K.:

Estimating variances and covariances for multivariate Animal Models by Restricted Maximum Likelihood. Genet. Sel. Evol. Les Ulis, 23 (1991), 67-83

NEUVY, A.; VISSAC B.:

Contribution à l'étude du phénomène culard. Union National des Livres Généalogiques (1962), Paris

ROLLINS, W.C.; TANAKA, M.; NOTT, C.F.G.; THIESSEN, R.B.:

On the mode of inheritance of double muscled conformation in bovines. Hilgardia, Oakland, 41 (1972), 433-456

SAS Institute INC:

SAS user's guide: Statistics. (1999) ed SAS Institute, Inc, Cary, NC, USA

SHI, M.J.; LALOÈ, D.; MENISSIER, F.; RENAND, G.:

Estimation of genetic parameters of preweaning performance in the French Limousin cattle breed. Genet. Sel. Evol., Les Ulis, 25 (1993), 177-189

VALLS ORTIZ, J.M.; MENISSIER, F.; VISSAC, B.:

Etude du caractère culard. VI. Transmission et posibilités de d'utilisationen croisement de prèmiere génération pour la production de veaux de boucherie. Ann. Genet. Sel. Anim., Les Ulis, 4 (1972), 7-28

VISSAC, B.; LAUVERGNE, J.J.:

Enquête sur le caractère culard dans la zone charolaise. Ann. Genet, Sel, Anim., Les Ulis, 1 (1969), 177 (Abstr.).

VISSAC, B.; MENISSIER, F.; PERREAU, B.:

Etude du caractère culard. VII. Croissance et musculature des femelles; déséquilibre morphologique au vêlage. Ann. Genet. Sel. Anim., Les Ulis, 5 (1973), 23-28

Received: 2001-08-16

Accepted: 2002-02-26

Author's addresses

FELIX GOYACHE*, PhD; UIS .J. ROYO, ISABEL ALVAREZ,

SERIDA-CENSYRA-Somió

C/ Camino de los Claveles 604,

E-33208 Gijón (Asturias), Spain

E-Mail:felixgg@princast.es

JUAN P. GUTIERREZ, PhD

Dpto. de Produccion Animal

Facultad de Veterinaria

E-28040 Madrid, Spain

*Corresponding author 